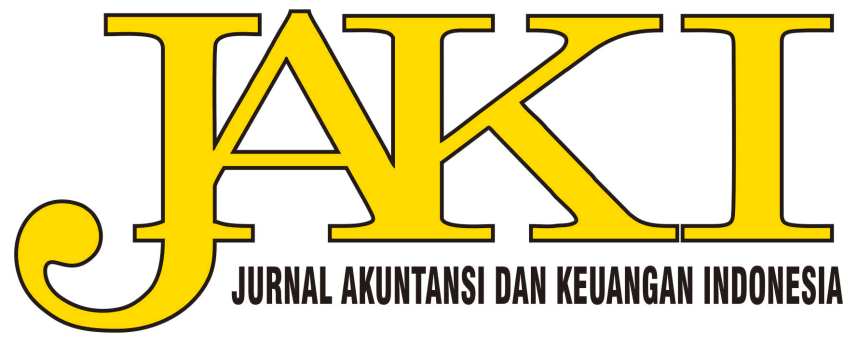

Volume 17

Issue 1 Volume 17, Issue 1, 2020

Article 4

$6-30-2020$

\title{
DOES THE RECENTLY IMPLEMENTED REGULATION ON COUNTRY-BY-COUNTRY REPORTING DETER TAX AVOIDANCE?
}

\author{
Nala Kurniawan \\ Directorate General of Taxes \\ Anggari Dwi Saputra \\ Directorate General of Taxes
}

Follow this and additional works at: https://scholarhub.ui.ac.id/jaki

Part of the Accounting Commons, Corporate Finance Commons, Finance and Financial Management Commons, and the Taxation Commons

\section{Recommended Citation}

Kurniawan, Nala and Saputra, Anggari Dwi (2020) "DOES THE RECENTLY IMPLEMENTED REGULATION ON COUNTRY-BY-COUNTRY REPORTING DETER TAX AVOIDANCE?," Jurnal Akuntansi dan Keuangan Indonesia: Vol. 17: Iss. 1, Article 4.

DOI: 10.21002/jaki.2020.04

Available at: https://scholarhub.ui.ac.id/jaki/vol17/iss1/4

This Article is brought to you for free and open access by the Faculty of Economics \& Business at UI Scholars Hub. It has been accepted for inclusion in Jurnal Akuntansi dan Keuangan Indonesia by an authorized editor of UI Scholars Hub. 
Jurnal Akuntansi dan Keuangan Indonesia

Volume 17 Nomor 1, Juni 2020

\title{
DOES THE RECENTLY IMPLEMENTED REGULATION ON COUNTRY-BY-COUNTRY REPORTING DETER TAX AVOIDANCE?
}

\author{
Nala Kurniawan \\ Directorate General of Taxes \\ nalakurniawan@gmail.com \\ Anggari Dwi Saputra \\ Directorate General of Taxes \\ anggaridicted@gmail.com
}

\begin{abstract}
To adhere with Base Erosion and Profit Shifting (BEPS) Action 13, Indonesia enacted regulations concerning Transfer Pricing Documentation and Country-by-Country Reporting $(\mathrm{CbCR})$ to address the issue of tax avoidance. Those regulations introduced the requirement of CbCR in Indonesia, where Multinational Enterprises (MNEs) operating in Indonesia are required to provide tax authorities with geographic breakdown of their profitability, tax payments, and activities wherever they operate. Using the newly implemented $C b C R$ in Indonesia as a treatment for private disclosure requirement, this study examines the effect of CbCR on MNEs tax avoidance. Employing EUR 750 million consolidated revenue threshold for disclosure and utilizing regression discontinuity design as well as difference-in-differences analysis, we document a 4-8 percentage point increase in effective tax rates among affected MNEs, thus reflecting a decrease in tax avoidance in treatment firms. Our findings contribute (i) to the recent empirical literature on how CbCR as a private disclosure affects corporate tax avoidance behavior and (ii) to the policy evaluation whether CbCR regulation has achieved its objective.
\end{abstract}

Keywords: Transfer Pricing; Country-by-Country Reporting; private disclosure; corporate taxation; tax avoidance

\begin{abstract}
Abstrak
Untuk memenuhi Base Erosion and Profit Shifting (BEPS) Aksi 13, Indonesia menerbitkan peraturan mengenai Dokumentasi Penentuan Harga Transfer dan mengenai Laporan per Negara (CbCR). Peraturan-peraturan tersebut memperkenalkan kewajiban pelaporan $\mathrm{CbCR}$ di Indonesia, di mana perusahaan multinasional yang beroperasi di Indonesia diwajibkan untuk memberikan rincian geografis mengenai profitabilitas, pembayaran pajak, dan aktivitas mereka di manapun mereka beroperasi kepada otoritas pajak. Dengan menggunakan $\mathrm{CbCR}$ yang baru diimplementasikan di Indonesia sebagai bentuk perlakuan bagi persyaratan pengungkapan privat, penelitian ini menguji pengaruh $\mathrm{CbCR}$ pada penghindaran pajak Perusahaan Multinasional (MNE). Dengan menggunakan batasan peredaran bruto konsolidasi sebesar EUR 750 juta untuk pengungkapan dan analisis regression discontinuity design serta difference-in-differences, kami membuktikan adanya peningkatan sebesar 4-8 persen dalam tarif pajak efektif di antara MNE yang terdampak kewajiban $\mathrm{CbCR}$, yang menggambarkan penurunan penghindaran pajak pada perusahaan yang memperoleh perlakuan. Temuan kami berkontribusi (i) pada literatur empiris terbaru tentang bagaimana $\mathrm{CbCR}$ sebagai pengungkapan privat memengaruhi perilaku penghindaran
\end{abstract}


pajak perusahaan dan (ii) pada evaluasi kebijakan apakah peraturan CbCR telah mencapai tujuannya.

\section{Kata kunci: Transfer Pricing; Laporan per Negara; pengungkapan privat; pajak perusahaan; penghindaran pajak}

\section{INTRODUCTION}

By enacting Minister of Finance Regulation No. 213/PMK.03/2016 (MoFR213/2016) concerning Transfer Pricing Documentation and Director General of Taxes Regulation No. 29/PJ/2017 (DGTR29/2017) concerning Procedures for Managing Country-by-Country Reporting $(\mathrm{CbCR})^{1}$, Indonesia adopts three-tiered approach to transfer pricing documentation consistent with Base Erosion and Profit Shifting (BEPS) Action $13^{2}$. The threetiered structure consists of (i) master file, containing information relevant for all Multinational Enterprise (MNE) group members; (ii) local file, describing specifically to related party transactions conducted by the local taxpayer as part of MNE group; and (iii) $\mathrm{CbCR}$, containing standardized information relating to the global allocation of the MNE's income and taxes paid along with certain indicators of economic activity where the MNE operates (OECD 2015). Those three documents are expected to improve the taxpayer's transparency for tax administration and finally help tax administration in tackling tax avoidance of the MNEs (OECD 2015).

Under BEPS Action 13, MoFR213/2016 and DGTR-29/2017, MNEs are required to submit annual CbCR to tax administrations through their Ultimate Parent Entities (UPEs). The aforementioned report

\footnotetext{
${ }^{1}$ Transfer Pricing Documentation in Minister of Finance Regulation No. 213/PMK.03/2016 consists of three documents, i.e. Master File, Local File, and Country-by-Country Reporting. The enactment of Director General of Taxes Regulation No. 29/PJ/2017 is only for clarifying the technical guidance on Country-by-Country per se.

${ }^{2}$ BEPS Action 13 is one of 15 Action Plans proposed by the OECD to address the issue of Base Erosion and Profit Shifting (BEPS) exploited by MNEs. There are several BEPS Action Plans falling within the category of minimum standards, i.e. BEPS
}

contained aggregated data for each jurisdiction where MNEs operate world-wide, including information on revenue, profit or loss before income tax, income tax paid, income tax accrued, stated capital, retained earnings, the number of employees, tangible assets, and lists of constituent entities ${ }^{3}$ for each jurisdiction and their activities (OECD 2015).

The CbCR obtained by tax administration from UPE of particular MNE group will then be exchanged with the other jurisdictions where the MNE group operates (OECD 2015). The availability of $\mathrm{CbCR}$ of MNE group and the exchange of the report to any jurisdiction where the MNE operates would close the information gap between MNE and tax administration, and even between tax administrations (OECD 2015). This is intended to enhance the capacity of tax risk assessment to better allocate the audit resource, and thus to deter aggressive tax planning (OECD 2017).

$\mathrm{CbCR}$ as required by BEPS Action 13, MoFR-213/2016, and DGTR-29/2017 is intended as a private disclosure. The nature as a private disclosure is in the sense that CbCR is only reported to the tax authority, yet not published to the society (Simone and Olbert 2020). It thus differs from CbCR as a public disclosure which should be made publicly available as required by European Union (EU) Capital Requirements Directive IV (CRD IV) for EU banking industry.

Action 5 (Counter Harmful Tax Practices), BEPS Action 6 (Prevent Treaty Abuse), BEPS Action 13 (Country-by-Country Report), and BEPS Action 14 (Improving Effectiveness of Dispute Resolution Mechanisms). As part of Inclusive Framework member countries, Indonesia is thus obliged to implement those minimum standards, including Country-by-Country Report.

${ }^{3}$ The scope of constituent entities pursuant to BEPS Action 13 and DGTR-29/2017 encompasses subsidiaries and Permanent Establishments (PEs) 
There have been ample researches examining how the impact of the introduction of $\mathrm{CbCR}$ requirement as public disclosure to corporate behavior through public accountability, for instance Dutt et al. (2019); Brown et al. (2019); Joshi et al. (2019); Overesch and Wolff (2019). However, there is still limited research studying the impact of $\mathrm{CbCR}$ as a private disclosure on corporate tax avoidance, except for Joshi (2020). Nevertheless, Joshi (2020) limits its studies solely on the behavior of EU MNE's Ultimate Parent Entity post the implementation of $\mathrm{CbCR}$ as private disclosure therein. It does not accordingly describe the whole picture of corporate tax avoidance from the perspective of capital importing countries where most of the subsidiaries of MNEs reside.

The effectiveness of private disclosure in addressing the problem of corporate tax avoidance will rely on its informativeness for tax authority in tax law enforcement. OECD (2015) claims that CbCR will provide the tax administration with a new information on MNE's global footprints, activities, and the related tax payments in the other jurisdictions. Pawar and Sabharwal (2016) described that before the implementation of CbCR, how tax administrations perceive an MNE group was akin to a group of blind men attempting to identify what an elephant looks like. With the information contained in CbCR, tax administrations are expected to comprehend a whole picture of how MNEs actually operate world-wide.

However, Hanlon (2018) and Spengel (2018) doubt this claim by pointing out that CbCR might be unable to assess whether the transfer pricing of the MNEs has been set appropriately and that heterogeneity of information in $\mathrm{CbCR}$ may dilute its informativeness. Accordingly, the effectiveness of $\mathrm{CbCR}$ in strengthening tax law enforcement and thus reducing corporate tax avoidance of MNEs is still questionable.

\footnotetext{
4 Assume the exchange rate of EUR to IDR = $17,463.13$ (the EUR-IDR exchange rate on 12 August 2020 based
}

This study is aimed to answer such a puzzle by examining whether there are any differences in corporate tax avoidance of MNEs in Indonesia before and after CbCR regulation. To empirically test it, we employ a regression discontinuity design and difference-in-differences analysis. In this study, our observation consists of MNEs operating in Indonesia irrespective where their UPEs reside. Furthermore, to separate the observation into treatment group and control group, we employ the consolidated revenue threshold as set out by BEPS Action 13. MNEs operating in Indonesia of the UPEs having consolidated revenue equal to or higher than EUR 750 million are treated as treatment group, otherwise - MNEs in Indonesia of the UPEs having consolidated revenue below EUR 750 million are treated as control group.

In this study, our main proxy for tax avoidance is Effective Tax Rate (ETR). For first analysis using firm-level regression discontinuity design, we document a sharp, positive, and significant discontinuity in tax avoidance at the cutoff: MNEs operating in Indonesia of the UPEs above CbCR threshold report higher ETRs, suggesting a decline in tax avoidance.

To support our first analysis, we also employ difference-in-differences model. There is a 4 to 8 percentage point increase in the ETRs (equal to approximately EUR 6 million - EUR 11 million or IDR 103.2 billion to IDR 192.5 billion increase in tax expense) of reporting MNEs (treatment group) post adoption of $\mathrm{CbCR}$, relative to non-reporting MNEs (control group) ${ }^{4}$. These results solidly indicate that the implementation of $\mathrm{CbCR}$ in Indonesia lead to a significant decline in corporate tax avoidance.

This study thus offers some contributions. First, we add to the existing literature by providing empirical evidence of the impact of $\mathrm{CbCR}$ as a private disclosure re

https://www.xe.com/currencytables/?from=EUR\&d ate $=2020-08-12$ 
quirement that applies to all MNEs in Indonesia. Unlike the previous study carried out by (Joshi 2020) which focuses solely on the impact of $\mathrm{CbCR}$ on EU headquartered MNEs, our study provides the impact of $\mathrm{CbCR}$ on MNEs operating in Indonesia, irrespective where their UPEs reside, considering the nature of Indonesia as a capital importing country. Our findings are however consistent with Joshi (2020) and even with higher magnitude of economic consequences, in terms of higher increase in the ETRs.

Second, this study provides the Directorate General of Taxes (DGT) with a new insight whether the adoption of $\mathrm{CbCR}$ as mandated by BEPS Action 13 has achieved the desired results, i.e. providing transparency and thus lowering the potential of tax avoidance. There has not been any empirical study examining the impact of $\mathrm{CbCR}$ regulation on MNEs operating in Indonesia. The result of this study is intended to fill the gap by answering the effectiveness of the introduction of $\mathrm{CbCR}$ regulation in Indonesia.

The rest of this article consists of several sections. Section 2 elaborates institutional background, literature review and hypothesis development. Section 3 describes the sample and research design. Section 4 reports our primary results and robustness check. Section 5 concludes this study.

\section{INSTITUTIONAL BACKGROUND, LITERATURE REVIEW, AND HYPOTHESIS DEVELOPMENT}

\section{Institutional Background: Country by- Country Reporting}

BEPS Action 13, MoFR-213/2016, as well as DGTR-29/2017 explain that CbCR provides the aggregated data on jurisdiction/country basis where the MNE group operates, consisting of the data of revenue

5 EUR 750,000,000 $\mathrm{x} 15,008.1816=\mathrm{IDR}$ $11,256,136,200,000 \approx$ IDR $11,000,000,000,000$. The from both related parties and unrelated parties, profit/loss before income tax, income tax paid, income tax accrued, stated capital, accumulated earnings, number of employees, and tangible assets other than cash and cash equivalents (OECD 2015). Aside from the above, $\mathrm{CbCR}$ also provides the information of the list of constituent entities located in each jurisdiction/country, including the information of their respective main business activities and any other relevant information encompassing all information described earlier.

Notwithstanding the first proposal by Murphy (2003) requiring MNEs to publicly disclose certain financial information for every jurisdiction in which they operate, as mandated by BEPS Action $13 \mathrm{CbCR}$ data is treated as confidential data, in which taxpayer as a UPE reports it directly to tax administration where it is administered without necessarily publishing it for society. Accordingly, it falls within the category of private disclosure. From information in CbCR, tax administrations may obtain any additional insights which are useful in assessing the tax risk (both transfer pricing risk and other BEPS risk) of a particular MNE (OECD 2017). Having a robust tax risk assessment, tax administrations may better allocate its resources to MNEs posing higher risk, and thus tackle the issue of corporate tax avoidance (OECD 2017).

BEPS Action 13 sets out the guideline that $\mathrm{CbCR}$ is only required for MNE group having consolidated group revenue of at least EUR 750 million. To adhere with BEPS Action 13, MoFR-213/2016 and DGR-29/2017 stipulates that MNEs with Indonesian UPEs are required to submit $\mathrm{CbCR}$ if their consolidated group revenues are at least IDR 11 trillion. This figure is actually equal with EUR 750 million based on EUR-IDR exchange rate on 1 January $2015 .^{5}$ Both regulations even further described that if the UPEs of the MNEs are

figure 15,008.1816 the EUR-IDR exchange rate on 1 January 2015 based on:

https://www.exchangerates.org.uk/historical/EUR/0 1_01_2015 
foreign entities, the threshold of consolidated group revenue will be EUR 750 million, following BEPS Action 13.

CbCRs are filed annually by the UPE for the entire MNE group members in the jurisdiction where UPE resides. To ensure that all tax administrations where MNE group operates obtain the same information, the OECD developed the Qualifying Competent Authority Agreement (QCAA) to enable the exchange of CbCRs between tax administrations, where tax administration receiving the CbCR from UPE of a particular MNE group will transmit it to the other jurisdictions where the constituent entities of the MNE group operate. As of August 2020, Indonesia has 75 QCAAs in effective with other jurisdictions to accommodate the exchange of CbCR (OECD 2020).

\section{Literature Review and Hypothesis Development}

\section{Agency Theory}

Jensen and Meckling (1976) defined an agency relationship as a contract under which principal engage the agent to perform services on behalf of the principal which is followed by delegating decision making authority to the agent. If the interest of both parties diverge, there is a possibility that the agent will not always act in the best interests of the principal. To address this agency problems, the principal can limit divergences from his interest by establishing appropriate incentives for the agent and by incurring monitoring costs designed to limit the deviation of agent.

The framework of the agency theory can also be used to understand the corporate tax avoidance (Hanlon and Heitzman 2010). Chen and Chu (2005), for instance, use principal-agent model in explaining the efficiency loss due to the incompleteness in contract when a principal hires an agent to engage in tax avoidance. Their study finds that if a firm intends to avoid taxes, it has to balance the tradeoff between two considerations, i.e. the increase of expected after-tax profit on one side, and the risk of being detected as well as the cost of efficiency loss in internal control on the other side.

Another study of corporate tax avoidance within agency framework is Crocker and Slemrod (2005). Crocker and Slemrod (2005) examine corporate tax avoidance in the context of the contractual relationship between the corporate shareholders and a tax manager of Chief Financial Officer (CFO) possessing private information concerning the reductions in taxable income. Their study finds a policy relevant result that penalties imposed on the tax manager are more effective in reducing tax avoidance than are those imposed on shareholders.

Further literature of agency theory in explaining corporate tax behavior is Desai et al. (2007). Desai et al. (2007) explain a situation where a self-interested manager structures a complex scheme to reduce corporate taxes and divert corporate resources for manager's private use. In this regard, Desai et al. (2007) argue that a strong enforcement from tax authority can provide additional monitoring of managers, and accordingly, the incentives of the outside shareholders are aligned with the tax authority in reducing diversion by managers.

\section{Corporate Tax Avoidance}

In their seminal paper, Allingham and Sandmo (1972) posit that individual tax compliance is determined by tax rates, the probability of detection and punishment, penalties and risk-aversion. However, Hanlon and Heitzman (2010) argued that these factors also apply to the corporate taxpayer. Slemrod (2004) also points out, additional issues arise in corporations because of the separation between ownership and control. Separation of ownership and control thus can lead to corporate tax decisions that reflect the private interests of the manager. However, within agency framework, if tax avoidance is a worthwhile activity, the owners should structure appropriate incentives to ensure that managers make tax-efficient decisions. 
Tax-efficient decisions could be understood from the Scholes and Wolfson (1992) framework. In the Scholes and Wolfson (1992) framework, effective tax planning is defined as steps taken by a firm to minimize its explicit tax burden. In this regard, Scholes and Wolfson (1992) model highlighted the importance of considering all parties, all taxes, and all costs in evaluating tax planning decision. Those three themes - all parties, all taxes and all costs provide a structure for tax management to achieve organizational goals, such as profit or wealth maximization (Shackelford and Shevlin, 2011). Consistent with this view, Dyreng et al. (2008) document that effective tax rates, as the most common measure of tax avoidance, are a choice variable, suggesting that firms can strategically avoid taxes over the long run.

\section{Tax Disclosures}

The existence of tax disclosures can provide the transparency for tax authority to reduce the asymmetrical information between tax authority and taxpayer and thus enables tax authority to detect the aggressive tax planning. The theory of tax evasion also predicts that taxpayer compliance will increase with higher probability of detection (Allingham and Sandmo 1972). If the disclosure to tax authority can increase the probability of detection, any costs related to arranging the aggressive tax planning will also increase. This will eventually reduce the level of corporate tax avoidance.

Sansing (1993) argues that the Internal Revenue Service (IRS) of the United States will engage in information acquisition activities and, subject to budget constraints, will rely more heavily on information signals that are more informative for the audit process. Through empirical study, Mills (1998) documents that increase in taxrelated disclosures can help tax authorities in decision making for allocating enforcement resources. Consistent with Mills (1998), Hoopes et al. (2012) also find that U.S. public firms undertake less aggressive tax positions when tax enforcement is stricter.

Nevertheless, Towery (2017) documents that US firms did not alter their tax behavior after being required to report a new information to IRS regarding Uncertain Tax Positions (UTP). In this study, Towery (2017) does not take into account for the informativeness of the disclosure.

Bozanic et al. (2016) recently examine how public and private disclosure requirements influence tax enforcement in the United States. Using IRS acquisition of a firm's public financial disclosures as a proxy for IRS attention, they find that the attention increased following an increase in the public tax disclosure requirements (e.g. Financial Accounting Standard Board Interpretation No. 48, Accounting for Uncertainty in Income Taxes). However, they also document that the attention decreases following an increase in private tax disclosure requirements (e.g. uncertain tax benefits). Considering this result, Bozanic et al. (2016) argue on the informativeness of the disclosure. Private disclosures will only be useful to tax authorities insofar as they provide new information on an entity's tax arrangement (Bozanic et al. 2016).

Further question may arise, whether $\mathrm{CbCR}$ as a private disclosure can be informative enough for tax authorities to increase enforcement and thus change corporate tax behavior. Considering that the information contained in CbCR is global and aggregate in nature, it is still unclear whether $\mathrm{CbCR}$ does provide incremental insights to tax authorities to assess the appropriateness MNE's transfer price (Hanlon 2018). Spengel (2018) also argued that the heterogeneity of the reports resulting from a lack of uniform implementation by different companies and countries will dilute the value of information contained in $\mathrm{CbCR}$ and consequently lead to misinterpretation.

However, Joshi (2020) argue that CbCR could provide the transparency for tax authorities to detect any misalignment between the profits generated in each country and the related tax payments. Moreover, 
not all tax authorities have a comprehensive access to financial and tax information on the MNE's global operations. This could be understood since $\mathrm{CbCR}$ provides the tax authority with a detailed breakdown of key operating, financial, activities, and tax metrics for all jurisdictions where the MNE operates.

Joshi (2020) then conducts empirical study to answer whether corporate tax avoidance decreases following the implementation of $\mathrm{CbCR}$ as a private disclosure in EU. Using EU headquartered MNEs as the observation, she empirically documents that there is a reduction in corporate tax avoidance of EU MNEs following the implementation of $\mathrm{CbCR}$ as a private disclosure. The study also reveals that CbCR deters tax avoidance through the increase of tax enforcement. This study is therefore consistent with the argument that $\mathrm{CbCR}$ as a private disclosure provides insightful information for tax authority thus strengthening tax enforcement and reducing corporate tax behaviour.

Taking into account the above theoretical arguments and the previous studies, including the empirical finding of Joshi (2020) above, we therefore hypothesize that:

\section{$\mathrm{H}_{1}$ : Corporate tax avoidance will decrease following the imple- mentation of CbCR.}

\footnotetext{
${ }^{6}$ Article 2 Paragraph 3 of MoFR-213/2016 indeed provides provision on the obligation to submit CbCR only for Indonesia-based UPE meeting the IDR 11 Trillion threshold on behalf of its group wherever the group members operate. For foreign-based UPE, the obligation to file $\mathrm{CbCR}$ will follow the regulation of respective country where the UPE resides. However, like MoFR-213/2016, CbCR regulation in any countries shall also align with BEPS Action 13 minimum standard, including the EUR 750 million threshold. In addition, Indonesia will also obtain the CbCR of foreign-based UPE which has subsidiary operating in Indonesia from the country of UPE through automatic exchange of information mechanisms, and vice versa. If due to some conditions Indonesia cannot obtain the $\mathrm{CbCR}$ of
}

\section{RESEARCH METHODS}

\section{Data and Sample}

Our primary sample consists of MNEs operating in Indonesia. Unlike Joshi (2020) which primarily focuses on the behavior of EU MNEs, i.e. EU-headquartered firms, considering the nature of Indonesia as a capital importing country, our main objective is to obtain evidence whether the implementation of CbCR affected tax avoidance on the MNEs operating in Indonesia, irrespective where the UPEs reside. ${ }^{6}$

There are several reasons for selecting Indonesia as the setting for this research. First, until now, there has not been any empirical research studying the change of corporate tax behavior of MNEs operating in Indonesia between prior and post the implementation of CbCR. Second, Indonesia has been one of primary destinations for MNEs through foreign direct investment in region of South East Asia, thanks to its large market size and considerable number of labor supply (Fernandez et al. 2020). Third, corporate tax avoidance has been a perennial issues for tax administration of Indonesia. Cobham and Jansky (2018) even estimated that in 2013 Indonesia lost approximately USD 6.48 billion to USD 7.48 due to MNE's corporate tax avoidance. This figure made Indonesia as the second largest developing countries suffering from tax avoidance, after China. Taking the above facts into consideration, this study then focuses on the corporate tax behavior of

foreign-based UPE through automatic exchange of information, Indonesia could still impose an obligation for foreign-based MNE operating in Indonesia to submit the CbCR of its group employing EUR 750 million threshold. It is also worth to mention that both the CbCR obtained from Indonesia-based UPE and the CbCR received from foreign-based UPE through the automatic exchange of information with the other countries will then be treated the same, i.e. as the input in assessing transfer pricing risk and other tax avoidance risks of the MNEs in Indonesia irrespective where the UPE resides. Accordingly, the regulation will affect the behaviour of Indonesia-based MNE and foreignbased MNE in the same way. 
Table 1

Sample Selection of MNEs Operating in Indonesia

\begin{tabular}{lr}
\hline Search Step & Step Results \\
\hline Active Companies & $283,923,475$ \\
Country : Indonesia & 107,625 \\
Ownership : an Ultimate Owner or shareholder owning together 51\% located anywhere (including & 17,649 \\
unknown countries); May have other shareholders located in country of origin; Subsidiaries located & \\
anywhere (including unknown countries) not ultimately owned but at least 51\% owned; May have & 17,556 \\
other shareholder in the foreign country; Def. of the UO: min. path of 50.01\%. known or unknown & 93 \\
shareholder & \\
Less firms missing required data i.e. Profit or Loss Before Tax, Tax Expense, Total Assets, Long & \\
Term Debt, and Intangible Assets & \\
Final sample &
\end{tabular}

Source: Orbis Database

MNEs operating in Indonesia and the changes thereto due to the implementation of $\mathrm{CbCR}$.

The governing principle to determine an MNE Group is to follow the accounting consolidation rules (OECD 2019). Hence, our sample should cover Indonesia-based UPEs preparing consolidated financial statements and any MNE subsidiaries being consolidated by foreign based UPEs. IFRS 10 indeed defines the existence of control when, one of which is power over the investee and holding majority of the voting rights is sufficient to give power over the investee $^{7}$. However, because our sample consists of observations for the years 2010-2019 in which there are observations where IFRS 10 is not yet in effect, for simplicity in determining holding majority of the voting rights, we use the threshold as addressed in the IAS 27, i.e. when the parent acquires more than half of the voting rights of the entity. Joshi (2020) also uses such threshold (i.e. $\geq 50 \%$ owned by the MNCs) in restricting the sample to majority-owned affiliates with regard to income-shifting test. In addition to that, De Simone and Olbert (2019) specify the consolidated firm as the parent entity and each of its subsidiaries owned by at least 50 percent directly by the parent or by another, higher tier, subsidiary of the same parent. Therefore, to ensure that our

\footnotetext{
${ }^{7}$ Holding majority of the Holding majority of the voting rights is sufficient to give power over the investee in the following situations : the relevant activities of the investee are directed by a vote of the holder of the majority of the voting rights; or a
}

sample consists of MNEs operating in Indonesia, i.e. either Indonesian UPEs that have foreign subsidiaries or subsidiaries in Indonesia whose UPEs located in foreign countries, we restrict the sample to active companies companies with more than $50 \%$ ownership or owned more than $50 \%$ by other companies.

We compiled the data of those companies, including the ownership data and the annual financial statements for the years 2010-2019 from Orbis database (Bureau van Dijk). As abovementioned, to separate our samples into treatment and control group, we employ UPEs consolidated revenue. On the other hand, to examine the tax avoidance behavior of our samples, we use the unconsolidated financial statement data of our sample.

Despite being formally introduced by the OECD through Final Report of BEPS Action 13 in 2015, Indonesia had just set out the requirement of $\mathrm{CbCR}$ since the promulgation of MoFR-213/2016 in December 2016. The details of CbCR requirement were then guided under DGTR29/2017 enacted in the following year. However, both regulations stipulated that the $\mathrm{CbCR}$ requirement has entered into force since fiscal year commencing on 1 January 2016. We therefore consider the post-implementation period to be from

majority of the members of the investee's governing body that directs the relevant activities are appointed by a vote of the holder of the majority of the voting rights. (IFRS 10.B35) 
2016 onward. Following Joshi (2020), due to the possibility for firms to take some time to adjust their tax planning, we also estimate the tax avoidance models by year.

Table 1 provides the steps taken to obtain the sample of our study. After excluding firms with missing data required to calculate the regression variables, the final sample consists of 93 MNEs operating in Indonesia (930 firm year-ends). Table 1 presents an overview of the sample selection.

\section{Measures of Tax Avoidance}

To measure tax avoidance, we employ Effective Tax Rate (ETR) consistent with (Joshi 2020). A higher (positive) ETR indicates a lower tax avoidance, and a lower (negative) ETR suggests a higher tax avoidance. This measure has been extensively used in previous studies and are appropriate for the large sample of MNEs (Hanlon and Heitzman 2010). As being pointed out by Hanlon and Heitzman (2010), the measures of tax avoidance should carefully consider the research question. Since our objective is to observe MNEs's tax avoidance behaviour resulted from intra-group transactions both pre and post the era of CbCR, GAAP ETR is considered to be capable of capturing such form of avoidance since another tax strategy that defers taxes (e.g., more accelerated depreciation for tax purposes) will not alter the GAAP ETR (Hanlon and Heitzman 2010). To test the robustness of the analysis we also employed the different measure of tax avoidance using book tax differences. $^{8}$

ETR is calculated as the tax expense divided by Pre-Tax Income (PTI) ${ }^{9}$. Following Joshi (2020), we also reset ETR at 0 and 1 to limit the influence of outliers and to be able to better interpret the results.

\section{Research Methods Regression Discontinuity Design}

\footnotetext{
${ }^{8}$ Following Hanlon (2005) we estimate total booktax differences by grossing up current tax expense by statutory tax rate $(25 \%)$
}

To identify the effect of CbCR on tax avoidance, the first empirical strategy that we use is a sharp regression discontinuity design (Joshi 2020). The rating variable in the regression discontinuity model is the UPEs' preceding year consolidated revenue of the MNEs operating in Indonesia with the EUR 750 million threshold as the cutoff and the outcome variable is tax avoidance.

Consolidated revenue is expected to be locally smooth across the threshold prior the implementation period. However, tax avoidance is expected to jump discontinuously at the EUR 750 million threshold (Khan et al. 2017). To generate unbiased estimates of the treatment effect in a regression discontinuity design, index assignment at the EUR 750 million threshold should be locally randomized (Hahn et al. 2001). In other words, the consolidated revenue shall not be easily manipulated by the MNEs (Joshi 2020). In this regard, manipulation of consolidated revenue, though possible, is uncommon for MNEs because they are required to alter the timing of revenue recognition, which can probably trigger further scrutiny (Joshi 2020)

In addition to the graphical analysis using binned scatterplot method, we also carried out the nonparametric regression discontinuity analysis to allow flexible functional firms (Hahn et al. 2001; Lee and Lemieux 2010; Tan 2013; Gao et al. 2016; Khan et al. 2017). This nonparametric regression discontinuity is performed by nonparametric local linear regression using a triangle kernel. Following the estimator of Nadaraya (1964) and Watson (1964), we estimate the following model:

$$
W_{i}^{0}(x):=\frac{K_{h}\left(x-X_{i}\right)}{\sum_{i=1}^{n} K_{h}\left(x-X_{i}\right)} .
$$

Where:

$\mathrm{X}$ : measured using ETR

Y: CBCR Variable, an indicator variable 1 for 2016 and subsequent years if

\footnotetext{
${ }^{9}$ We use the GAAP effective tax rate, the ratio of total expense to pretax income that are disclosed in the income statement, as explanined by Dyreng et al. (2008)
} 
consolidated revenue of the UPEs in the preceding taxation year was at least EUR 750 million and zero otherwise.

$\mathrm{H}$ : the bandwidth option, we test the sensitivity of the results to the selected bandwidth by re-estimating the biascorrected treatment coefficient for three other fixed bandwidths $( \pm 250$, 450, and 550).

$\mathrm{K}$ : (kernel) we use the triangle kernel which is also used by Joshi (2020) to analyze the impact of $\mathrm{CbCR}$ on tax avoidance.

\section{Difference-in-Differences Analysis}

To identify the effect of CbCR on tax avoidance, considering the lack of generalizability associated with regression discontinuity models, we also use difference-in-differences analysis. In this analysis, the treatment (control) group consists of all MNEs operating in Indonesia whose UPEs have consolidated revenue of at least (less than) EUR 750 million in the preceding fiscal year commencing from 2016 (Joshi 2020). The use of EUR 750 million as a threshold is consistent with both BEPS Action 13 Minimum Standard adopted globally and MoFR-213/2016 as well as DGTR-29/2017 concerning CbCR.

We estimate the following baseline model constructed by Joshi (2020) to test for the impact of $\mathrm{CbCR}$ on tax avoidance.

$$
\begin{aligned}
& T A_{i t}=\alpha+\beta_{1} C B C R_{i t}+\beta_{2} P O S T_{i t}+\beta_{3} \\
& P O S T \times C B C R_{i t}+\beta X_{i t}+\varepsilon_{i t}
\end{aligned}
$$

TA is tax avoidance measured through ETR. CBCR is an indicator variable equal to 1 in $2010-2019$ if the firm is subject to CbCR requirement in 2016-2019 and 0

\footnotetext{
10 To implement a true difference-in-differences design, we need to compare the pre- and post-tax avoidance in treatment and control groups. As illustrated by Joshi 2020, we classify firms with consolidated revenue of more than EUR 750M in the preceding taxation year (commencing in 2016) as treatment firms for all periods (pre and post). Therefore. we compare tax avoidance in firms above
}

otherwise. ${ }^{10}$ POST is an indicator variable equal to 1 for all years in which the full CBCR requirements were in effect (20162019) and 0 otherwise (2010-2015). $X_{\text {it }}$ is a vector of control variables. Reasons for including control variables in above difference-in-differences model are for efficiency, checks for randomization, and adjusting for conditional randomization (Roberts and Whited 2013). Following Dyreng et al. (2008); Hoopes et al. (2012); Donohoe (2015); Chen (2017); Edwards et al. (2016), we incorporate the following variables in the model: profitability (ROA), size (LogTA), debt level (Leverage), intangible assets (Intang), and R\&D. Hoopes et al. (2012) stated that including endogogenous right-hand side variables as controls for factors that affect the budget set of the firm is a common practice in accounting research. In this regard, we employed control variables that affect the ability or incentives of firms to practice tax avoidance and to clarify the CbCR variable on tax avoidance. ${ }^{11}$ ROA controls profitability, regardless of the inconsistent results obtained for this variable based on prior researchs (e.g. Gupta and Newberry 1997; Adhikari et al. 2006 in Richardson et al. 2013). Size is applied to controls size effect, previous researchs (e.g. Tran 1997; Richardson and Lanis 2007; Richardson et al. 2013) find that larger firms are more likely to be tax aggressive because they possess superior economic and political power relative to smaller firms (Siegfried 1972) and are able to reduce their tax burdens accordingly. Leverage is utilized to control the incentives of firms to exercise tax avoidance due to tax-deductible interest payments (Richardson et al. 2013). Intang is used to control the effect of intangible asset accelerated depreciation charges

and below the EUR 750M cutoff before and after the implementation of CbCR under BEPS Action 13.

11 The option of these control variables, i.e. profitability (ROA), size (LogTA), debt level (Leverage), intangible assets (Intang), and R\&D, closely describe recent research on the determinant of corporate tax avoidances (e.g. Dyreng et al. 2008; Hoopes et al. 2012; Donohoe 2015; Chen 2017; Edwards et al. 2016) 
Table 2

Industry Classification

\begin{tabular}{lrr}
\hline Major Industry Sector & Freq. & Percent \\
\hline Agriculture. Horticulture \& Livestock & 6 & $6 \%$ \\
Banking. Insurance \& Financial Services & 2 & $2 \%$ \\
Business Services & 1 & $1 \%$ \\
Chemicals. Petroleum. Rubber \& Plastic & 15 & $16 \%$ \\
Communications & 2 & $2 \%$ \\
Construction & 3 & $3 \%$ \\
Food \& Tobacco Manufacturing & 11 & $12 \%$ \\
Industrial. Electric \& Electronic Machinery & 1 & $1 \%$ \\
Leather. Stone. Clay \& Glass products & 3 & $3 \%$ \\
Media \& Broadcasting & 3 & $3 \%$ \\
Metals \& Metal Products & 8 & $9 \%$ \\
Mining \& Extraction & 6 & $6 \%$ \\
Miscellaneous Manufacturing & 1 & $1 \%$ \\
Property Services & 6 & $6 \%$ \\
Retail & 5 & $5 \%$ \\
Textiles \& Clothing Manufacturing & $53 \%$ \\
Transport Manufacturing & 5 & $5 \%$ \\
Transport. Freight \& Storage & 2 & $2 \%$ \\
Travel. Personal \& Leisure & 2 & $5 \%$ \\
Wholesale & 5 & $2 \%$ \\
Wood. Furniture \& Paper Manufacturing & 2 & $5 \%$ \\
Grand Total & 4 & $5 \%$ \\
\hline & 5 & $5 \%$ \\
\hline
\end{tabular}

on tax avoidance, while $\mathrm{R} \& \mathrm{D}$ is associated with tax avoidance owing to tax-deductible R\&D expenditure (Richardson et al. 2013).

To minimize the impact of potential bias on the results from non-random treatment assignment, we use two multivariate reweighting techniques to enhance the covariate balance between the treatment and the control groups. We employ inverse probability weighting and entropy balancing multivariate technique. The use of these techniques reduces the potential bias due to non-random treatment assignment and also reduces model dependency for the subsequent analysis of treatment effects in the pre-processed data using standard methods such as regression analysis (Abadie and Imbens 2011).

In inverse probability weighting techniques, we use a weighted regression model, where observations are weighted to ensure similarity on some observed charac- teristics (Joshi 2020). This approach is similar to the inverse probability of treatment weighting and the "groups" to be weighted reflect both treatment status as well as time (pre-implementation vs. post-implementation) (Stuart et al. 2014). Specifically, we follow (Stuart et al. 2014)'s weighting strategy that reweights the four groups (treatment pre, treatment post, control pre, and control post) to be similar on a set of main covariates which are leverage, size, return on assets (ROA), intangible assets, and profitability.

The second method we use is entropy balancing which is based on a maximum entropy reweighting scheme that enables users to fit weights that satisfy a potentially large set of balance constraint involving exact balance on the first, second, and possibly higher moments of the covariate distributions in the treatment and the reweighted control group (Hainmueller and $\mathrm{Xu} 2013$ ). 
Table 3

Descriptive Statistics

\begin{tabular}{|c|c|c|c|c|c|c|}
\hline \multirow{2}{*}{$\begin{array}{l}\text { Panel A } \\
\text { Variable }\end{array}$} & \multicolumn{6}{|c|}{$\begin{array}{c}\text { Treatment Group - MNCs Operating in Indonesia with UPE's Consolidated } \\
\text { Revenue } \geq \text { EUR } 750 \text { million }\end{array}$} \\
\hline & 1 & Mean & $S D$ & P25 & P50 & P75 \\
\hline UPERev (mEuro) & 460 & $13,666.350$ & $22,019.550$ & $1,612.647$ & $6,076.419$ & $17,225.550$ \\
\hline PTI (mEuro) & 460 & 137.4377 & 325.0721 & 3.9599 & 19.9463 & 107.7260 \\
\hline $\begin{array}{l}\text { Total Assets } \\
\text { (mEuro) }\end{array}$ & 460 & $1,334.228$ & $2,662.798$ & 107.675 & 437.075 & $1,558.527$ \\
\hline SIZE & 460 & 8.690355 & 0.712921 & 8.115956 & 8.735980 & 9.261537 \\
\hline ROA & 460 & 11.11137 & 15.48533 & 1.76750 & 7.62750 & 16.19300 \\
\hline LEVERAGE & 460 & 0.1281959 & 0.205296 & 0 & 0.0445404 & 0.1962982 \\
\hline ETR & 460 & 0.2529504 & 0.1771401 & 0.1922743 & 0.2525055 & 0.2906412 \\
\hline INTANG & 460 & 0.022575 & 0.0631617 & 0 & 0.0011545 & 0.0130285 \\
\hline RND & 460 & 0.0038274 & 0.0263739 & 0 & 0 & 0 \\
\hline \multicolumn{7}{|l|}{ Panel B } \\
\hline $\begin{array}{l}\text { UPERev } \\
\text { (mEuro) }\end{array}$ & 470 & 152.8086 & 180.0229 & 20.8701 & 83.5416 & 207.5353 \\
\hline PTI (mEuro) & 470 & 12.6557 & 33.4086 & 0.2134 & 3.1601 & 14.9537 \\
\hline $\begin{array}{l}\text { Total Assets } \\
\text { (mEuro) }\end{array}$ & 470 & 260.2668 & 414.0686 & 33.3824 & 03.0010 & 313.3626 \\
\hline SIZE & 470 & 8.0852 & 0.6405 & 7.6078 & 8.0970 & 8.5753 \\
\hline ROA & 470 & 4.4240 & 9.4159 & 0.6560 & 4.5435 & 9.4220 \\
\hline LEVERAGE & 470 & 0.1146 & 0.1460 & 0.0001 & 0.0488 & 0.1873 \\
\hline ETR & 470 & 0.2382 & 0.2106 & 0.1019 & 0.2291 & 0.2848 \\
\hline INTANG & 470 & 0.0134 & 0.0638 & 0 & 0 & 0.0010 \\
\hline RND & 470 & 0.0007 & 0.0035 & 0 & 0 & 0 \\
\hline
\end{tabular}

All continuous variables are in millions of Euros. UPERev refers to the consolidated revenue for the corporate group; PTI refers to pretax earnings at the firm level; Size refers to the natural log of total assets; ROA is the return on assets and is calculated as net income divided by total assets; Leverage is long-term debt divided by total assets; ETR is calculated as total tax expenses divided by PTI; ETR has been reset at 1 and 0; INTANG is calculated as total intangible assets divided by total assets; and RND is calculated by total R\&D expenses divided by total assets.

We set the balancing constraints to the first order of moment.

\section{RESULT AND ANALYSIS}

\section{Summary and Descriptive Statistics}

Table 2 describes sample firms by industry based on NACE industry classification. Chemicals. Petroleum. Rubber and Plastic Industries comprise $16 \%$ of the sample, followed by Food and Tobacco Manufacturing, which comprise $12 \%$. Table 3 reports descriptive statistics separately for MNEs based on UPEs' consolidated revenue, between those of above (treatment) and those of below (control) the EUR 750 million threshold. As we expect, firms in the treatment group are larger and more profitable. We also included mean difference test to obtain initial evidence whether there are any differences between treatment and control group. Table 3 measures the t-test $p$-values of each variable used in this study.

As shown in Table 4, there is no significant difference mean between treatment and control group within Pre-CbCR implementation period. On the contrary, in the Post-CbCR implementation period, there is a significant difference mean between treatment and control group. This results may provide preliminary evidence indicating lower tax avoidance in firms subject to CbCR following disclosure requirement. 
Table 4

Mean Different Test

\begin{tabular}{|c|c|c|c|c|c|c|c|}
\hline \multirow[b]{3}{*}{$\begin{array}{l}\text { Treatment } \\
\text { Group } \\
\text { Control } \\
\text { Group }\end{array}$} & \multirow{2}{*}{$\begin{array}{l}N \\
460\end{array}$} & \multicolumn{6}{|c|}{ p-Values } \\
\hline & & ETR & SIZE & ROA & $\begin{array}{l}\text { LEVE } \\
\text { RAGE }\end{array}$ & $\begin{array}{c}\text { INTAN } \\
\mathbf{G} \\
\end{array}$ & RND \\
\hline & 460 & $\begin{array}{l}\text { Pre-Implementation : } 0.7852 \\
\text { Post-Implementation : } 0.0348^{*}\end{array}$ & $0.0000 *$ & $0.0000 *$ & 0.2439 & $0.0280^{*}$ & $0.0114 *$ \\
\hline
\end{tabular}

This table reports p-values each variables around the EUR 750M threshold. * Indicates statistical significance at 0.05.

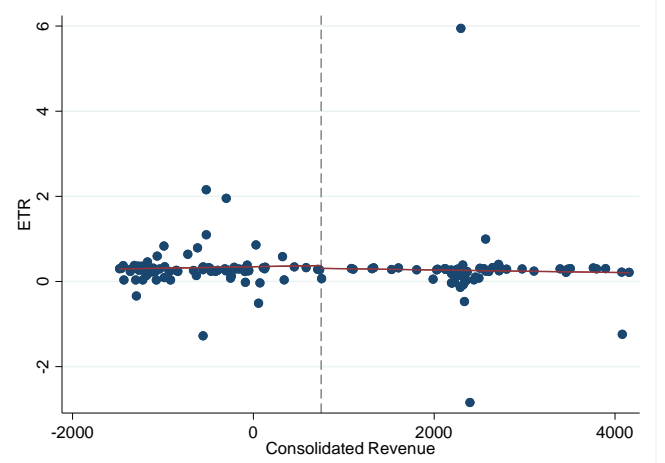

Figure 1

Regression Discontinuity

Plot of Tax Avoidance

(Pre-Implementation Period)

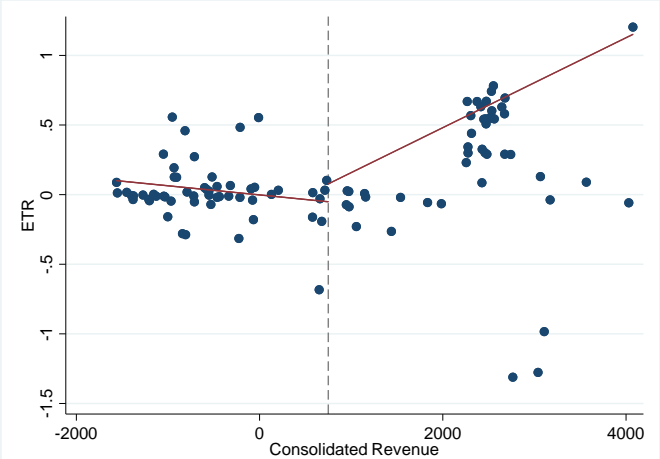

Figure 2

Regression Discontinuity

Plot of Tax Avoidance

(Post-Implementation Period)

Source: Authors' Calculation, STATA

Note:

Figure 1 plots ETRs against around the EUR 750M cutoff in the pre-implementation period (2010-2015). The vertical line is centered on EUR 750M. We winsorized Consolidated Revenue since there are enormous differences in the distributional of the data.

Figure 2 plots ETRs against around the EUR 750M cutoff in the post-implementation period (2016-2018). The vertical line is centered on EUR 750M. We winsorized Consolidated Revenue data since there are enormous difference in the distributional of the data.

\section{Empirical Results}

\section{Regression Discontinuity Analysis Graphical Presentation}

Following Joshi (2020), we start our analysis with a graphical presentation since it initially gives visual evidence of any discontinuity in the outcome variable at the cutoff. ${ }^{12}$ Figure 1 illustrates the ETR plot around EUR 750 million cutoff. Before the implementation of $\mathrm{CbCR}$, there was little to no discontinuity in ETRs at the threshold point.

\footnotetext{
12 The graphs in Figure 1 have been plotted using binned scatter method (Chetty et al. 2019). As explained Chetty et al. (2019) we residualize ETR with respect to the UPERev by CBCR variable. As set out by Starr and Goldfarb (2020), the residualized binned scatterplot is only rarely
}

Then, we plot ETR around the EUR 750 million threshold in the post-implementation period as illustrated by Figure 2. In contrast to Figure 1, the post-implementation period graphs in Figure 2 exhibits a positive discontinuity in the ETRs at the EUR 750 million cutoff. These graphs provide initial visual evidence suggesting lower tax avoidance in firms subject to $\mathrm{CbCR}$ following disclosure.

Taken together, Figures 1 and 2 represent tax behaviour consistent with expectations in the pre-implementation period

reflective of the true, conditional non-parametric relationship. Notably, if the controls are correlated with the variable of interest, then the shape of the binned scatterplot will be in accurate. Therefore, we must residualize to recover the true relationships. 
Table 5

Univariate Analysis ${ }^{13}$ of Tax Avoidance

\begin{tabular}{lcccccc}
\hline \hline & 250 & 250 & 450 & 450 & 550 & 550 \\
Variables & <EUR 750M & $>$ EUR 750M & < EUR 750M & $>$ EUR 750M & < EUR 750M & $>$ EUR 750M \\
\hline ETR & 0.2469 & 0.2790 & 0.2508 & 0.2797 & 0.2472 & 0.2802 \\
\hline
\end{tabular}

This table reports the mean tax avoidance around the EUR 750M threshold in the post-implementation period (2016-2018).

ETR is calculated as total tax expenses divided by pretax income.

Table 6

Regression Discontinuity Analysis of Tax Avoidance

\begin{tabular}{lcrr}
\hline \hline \multicolumn{1}{l}{ Panel A: Pre-implementation period } & & \\
\hline BW & $\mathbf{2 5 0}$ & $\mathbf{4 5 0}$ & $\mathbf{5 5 0}$ \\
\hline CBCR (ETR) & 0.0122 & 0.0132 & 0.0108 \\
& $(0.790)$ & $(0.801)$ & $(0.772)$ \\
CBCR (ETR_C) & 0.0034 & 0.0099 & 0.0068 \\
& $(0.456)$ & $(0.589)$ & $(0.534)$ \\
\hline Panel B: Post-implementation period & & \\
\hline BW & $\mathbf{2 5 0}$ & $\mathbf{4 5 0}$ & $\mathbf{5 5 0}$ \\
\hline CBCR (ETR) & $0.0605^{*}$ & $0.0640^{*}$ & $0.0647^{*}$ \\
& $(0.010)$ & $(0.033)$ & $0.038)$ \\
CBCR (ETR_C) & $0.0850^{*}$ & $0.0853^{*}$ & $0.0834^{*}$ \\
& $(0.014)$ & $(0.018)$ & $(0.011)$ \\
\hline
\end{tabular}

Table 6 reports the results of estimating a nonparametric local linear regression using triangle kernel. Panel A reports the results for the pre-implementation period (2010-2016). CBCR is an indicator variable equal to 1 (0) in 20162019. If consolidated revenue in the preceding year is at least (less than) EUR 750M. 250, 450, 550 bandwidths are used to estimate the nonparametric regression in the first, second, and third column. The outcome variable in the first and second row is ETR. ETR is calculated as the total annual tax expense by the pretax income. ETR is reset at 1 and 0 . The second row reports the results with the additional covariates (Leverage, Size, and ROA). $p$-values are reported in the parentheses and $*$ indicates statistical significance at 0.05 .

and furnish initial evidence of a decline in tax avoidance by treatment firms in the postimplementation period.

\section{Nonparametric Results}

After obtaining the visual evidence of the discontinuity, we then use nonparametric methods to investigate further the effect of $\mathrm{CbCR}$ on tax avoidance. We first compare the post-implementation mean tax avoidance for the two groups of firms because a comparison of means is the most straightforward nonparametric approach (Joshi 2020). We present the results in Table 5.

As we can refer, ETR of the treatment firms is higher compared to the control firms in all bandwidths. The comparison of means depicted in Table 5 thus suggests that tax avoidance is reduced by the time CbCR was implemented.

To mitigate the bias around the cutoff inherent to the means comparison test (Chen et al. 2019), we also utilize a nonparametric regression discontinuity design as presented by Table 6. CBCR variable is 1 for 2016 and the following years in case UPE's consolidated revenue in the preceding fiscal year was at least EUR 750 million and zero otherwise. We cluster biascorrected standard errors at the firm level. The $p$-value (based on the $\mathrm{Z}$ statistics) is presented in parentheses.

Panel A of Table 6 estimates the regression discontinuity test in the pre-implementation period when there should be no discontinuity in tax avoidance around the EUR 750 million threshold. Accordingly,

\footnotetext{
${ }^{13}$ Univariate analysis is defined as analysis carried out on only one ("uni") variable ("variate") to summarize or describe the variable (Babbie, 2007; Trochim and Donnelly, 2006). Univariate analysis is a relatively simple yet fundamental type of quantitative analysis used to summarize or describe one variable at a time across cases (Babbie, 2007; Trochim and Donnelly, 2006).
} 
Table 7

Difference-in-Difference Analysis of Tax Avoidance

\begin{tabular}{|c|c|c|c|c|c|}
\hline \multirow{2}{*}{\multicolumn{2}{|c|}{$\begin{array}{l}\text { Panel A: } \\
\text { Without multivariate reweighting } \\
\text { techniques }\end{array}$}} & \multicolumn{4}{|c|}{ "ETR } \\
\hline & & (1) & (2) & (3) & (4) \\
\hline CBCR*POST & & $0.048^{*}$ & $0.044^{*}$ & $0.045^{*}$ & $0.043^{*}$ \\
\hline$\beta_{3}$ & & $(0,021)$ & $(0,032)$ & $(0,030)$ & $(0,037)$ \\
\hline \multirow[t]{2}{*}{ ROA } & & & 0.000 & 0.000 & 0.000 \\
\hline & & & $(0,284)$ & $(0,271)$ & $(0,306)$ \\
\hline \multirow[t]{2}{*}{ SIZE } & & & -0.005 & -0.006 & -0.007 \\
\hline & & & $(0,457)$ & $(0,450)$ & $(0,448)$ \\
\hline \multirow[t]{2}{*}{ LEVERAGE } & & & $-0.0824 *$ & $-0.081^{*}$ & $-0.081 *$ \\
\hline & & & $(0,014)$ & $(0,015)$ & $(0,014)$ \\
\hline \multirow[t]{2}{*}{ INTANG } & & & & $0.212 *$ & $0.213^{*}$ \\
\hline & & & & $(0,048)$ & $(0,048)$ \\
\hline \multirow[t]{2}{*}{$\mathrm{R} \& \mathrm{D}$} & & & & 0.076 & 0.069 \\
\hline & & & & $(0,357)$ & $(0,368)$ \\
\hline \multirow[t]{2}{*}{ AvgSTR } & & & & & -0.703 \\
\hline & & & & & $(0,176)$ \\
\hline & $\sqrt{ }$ & $\sqrt{ }$ & $\sqrt{ }$ & $\sqrt{ }$ \\
\hline \multicolumn{2}{|l|}{ SE Clustered } & Firms & Firms & Firms & Firms \\
\hline \multicolumn{2}{|l|}{$\mathrm{N}$} & 930 & 930 & 930 & 930 \\
\hline \multicolumn{2}{|l|}{ R-sq. } & 0.2860 & 0.2887 & 0.2903 & 0.2910 \\
\hline
\end{tabular}

this test serves as a falsification or placebo test to validate the regression discontinuity design in this setting (Joshi 2020). As we expected, all columns in Panel A of Table 6 report an insignificant coefficient on CBCR.

Panel B of Table 6 reports the regression discontinuity results for the post-implementation period. The coefficients on CBCR are positive and statistically significant in all bandwidths. This result is consistent with Table 5 where treatment firms generate higher ETRs relative to control firms and therefore lower tax avoidance. The magnitude of the discontinuity ranges from 0.0605 to 0.0647 .

To improve the accuracy and for comprehensiveness as outlined by Joshi (2020), we also re-estimate the nonparametric model by adding several determinants of tax avoidance, such as total assets, leverage, and return on assets (Wilde and Wilson 2018). These results are presented in the second columns of Panel A and B of Table 6. We could infer that adding some determinants of tax avoidance still results in the positive coefficient of CBCR and statistically significant in all bandwidths. The coefficients on CBCR are in the magnitude from 0.0834 to 0.0850 . To sum up, Figure 1 and 2 as well as Table 5 and Table 6 collectively provide solid evidence of a decline in tax avoidance in treatment firms after the implementation of $\mathrm{CbCR}$.

\section{Difference-in-Difference Analysis}

Table 7 presents the results of the equation of difference-in-differences analysis using OLS estimation with robust standard error. The coefficient of interest in Table 6 is $\beta 3$, since it specifies an estimate of the impact of $\mathrm{CbCR}$ on tax avoidance in the treatment group relative to the control group in the post-implementation period (Joshi 2020). All columns of Table 6 incorporate firm and year fixed effect and standard errors are clustered at the firm level. ${ }^{14} \beta 3$ is positive and statistically significant in most estimations of Table 7 Panel A showing that treatment firms have higher ETR and hence, lower tax avoidance following the introduction of CbCR relative to control firms.

\footnotetext{
${ }^{14}$ Due to the inclusion of firm and year fixed effects. the CBCR and POST terms are dropped and not reported in the Table 6 .
} 
To mitigate the effect of potential bias arising from non-random treatment assignment on the results in Table 7 Panel A, we use two multivariate reweighting techniques to enhance the covariate balance between the treatment and the control groups (Joshi 2020). Panel B of Table 7 presents the results from the incorporation of entropy balancing in the equation (columns 1 to 4 ) and inverse probability weighting (columns 5 to 8). Comparing between Panel $\mathrm{A}$ and Panel B of Table 7, we could conclude that coefficient estimates of both panels are similar. These results are therefore robust to non-random treatment assignment.

The results in Table 7 Panel A and Panel B provide a solid evidence of an increase in ETRs (or a reduction in tax avoidance) in the treatment firms relative to the control firms after the introduction of $\mathrm{CbCR}$ in Indonesia. Coefficient estimates suggest that in the post-implementation period, the ETRs of treatment firms are 4 to 8 percentage point higher than those of the control firms which indicates a decline in tax avoidance.

Using the results of difference-in-differences analysis, we could quantify the magnitude of CbCR in the firms' increase of tax expenses. If we use the mean PTI of the treatment group of EUR 137.4377 million and impose the coefficient estimates in Table 7, we will obtain an increase in accounting tax expense of EUR 6 million to EUR 11 million or IDR 103.2 billion to IDR 192.5 billion for an average treatment firm. ${ }^{15}$

\footnotetext{
${ }^{15}$ Assume the exchange rate of EUR to IDR = 17,463.13 (the EUR-IDR exchange rate on 12 August 2020 based on:
}

https://www.xe.com/currencytables/?from=EUR\&d ate $=2020-08-12$ 
Table 7- Continued

\begin{tabular}{|c|c|c|c|c|c|c|c|c|}
\hline \multirow{2}{*}{$\begin{array}{l}\text { Panel B: With entropy multivariate reweighting } \\
\text { techniques }\end{array}$} & \multicolumn{4}{|c|}{ ETR-Entropy Balancing } & \multicolumn{4}{|c|}{ ETR-Inverse Probability Weighting } \\
\hline & (1) & (2) & (3) & (4) & (5) & (6) & (7) & (8) \\
\hline CBCR*POST & $0.0733^{*}$ & $0.0793 *$ & $0.0802 *$ & $0.0715^{*}$ & $0.048^{*}$ & $0.046 *$ & $0.0468 *$ & $0.0448 *$ \\
\hline$\beta_{3}$ & $(0,010)$ & $(0,006)$ & $(0,006)$ & $(0,012)$ & $(0,019)$ & $(0,025)$ & $(0,023)$ & $(0,028)$ \\
\hline \multirow[t]{2}{*}{ ROA } & & $-0.0020 *$ & $-0.0020 *$ & $-0.0022 *$ & & 0.000 & 0.000 & 0.000 \\
\hline & & $(0,009)$ & $(0,009)$ & $(0,006)$ & & $(0,453)$ & $(0,444)$ & $(0,474)$ \\
\hline \multirow[t]{2}{*}{ SIZE } & & $0.1102 *$ & $0.1097 *$ & $0.1081^{*}$ & & 0.012 & 0.012 & 0.012 \\
\hline & & $(0,002)$ & $(0,002)$ & $(0,002)$ & & $(0,408)$ & $(0,413)$ & $(0,413)$ \\
\hline \multirow[t]{2}{*}{ LEVERAGE } & & -0.0550 & -0.0550 & -0.0555 & & $-0.077^{*}$ & $-0.075^{*}$ & $-0.075^{*}$ \\
\hline & & $(0,076)$ & $(0,078)$ & $(0,073)$ & & $(0,037)$ & $(0,041)$ & $(0,039)$ \\
\hline \multirow[t]{2}{*}{ INTANG } & & & 0.0265 & 0.0327 & & & 0.190 & 0.191 \\
\hline & & & $(0,062)$ & $(0,397)$ & & & $(0,068)$ & $(0,068)$ \\
\hline \multirow[t]{2}{*}{$\mathrm{R} \& \mathrm{D}$} & & & 0.2870 & 0.2601 & & & 0.049 & 0.041 \\
\hline & & & $(0,1037)$ & $(0,089)$ & & & $(0,389)$ & $(0,406)$ \\
\hline \multirow[t]{2}{*}{ AvgSTR } & & & & $-1.819^{*}$ & & & & -0.570 \\
\hline & & & & $(0,023)$ & & & & $(0,231)$ \\
\hline Firm \& Year FE & $\sqrt{ }$ & $\sqrt{ }$ & $\sqrt{ }$ & $\sqrt{ }$ & $\sqrt{ }$ & $\sqrt{ }$ & $\sqrt{ }$ & $\sqrt{ }$ \\
\hline $\mathrm{N}$ & 930 & 930 & 930 & 930 & 930 & 930 & 930 & 930 \\
\hline R-sq. & 0.6925 & 0.6976 & 0.6977 & 0.7002 & 0.2883 & 0.2899 & 0.2909 & 0.2913 \\
\hline
\end{tabular}

$T A_{i t}=\alpha+\beta_{1} C B C R_{i t}+\beta_{2} P O S T_{i t}+\beta_{3} P O S T \times C B C R_{i t}+\beta X_{i t}+\varepsilon_{i t}$

Where TA is the tax avoidance variable and is measured using ETR. CBCR is an indicator variable equal to (0) 1 in 2010-2019 if the firm is (not) subject to CbCr rules in 2016-2019. POST is an indicator variable equal to 1 for all years in which the full CBCR requirements were in effect (2016-2019) and 0 otherwise (2010-2015). Xit is a vector of control variables. Panel B reports OLS estimates of the equation above adjusted for the weights resulted from entropy balancing exercise and inverse probability weighting. All columns are estimated with firm and year fixed effects. Due to the inclusion of the year fixed effect. CBCR and POST terms drops from the estimation and as such these terms are not reported in this table. Panel A estimated using White (1980) heteroscedasticity-consistent diagonal standard errors. p-values are reported in the parentheses and * indicates statistical significance at 0.05 . 

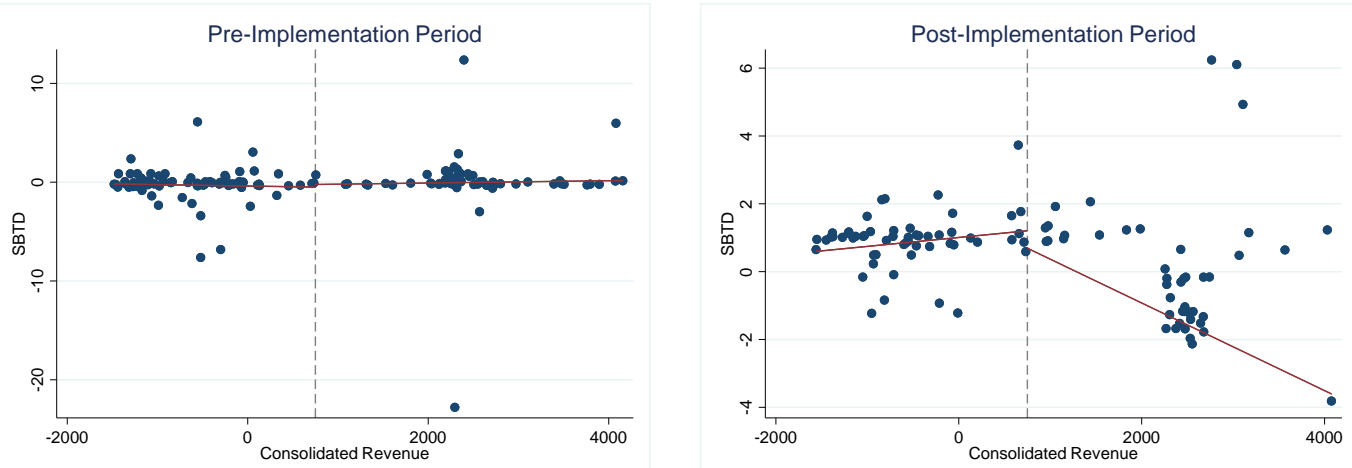

Figure 3

Regression Discontinuity Plot of Tax Avoidance (Pre and Post Implementation Period)

Source: Authors' Calculation, STATA

Note: Figure 3 plots SBTDs against around the EUR 750M cutoff in the pre-implementation period (20102015) (left figure) and in the post-implementation period (right figure). The vertical line is centered on EUR $750 \mathrm{M}$. We winsorized Consolidated Revenue since there are enormous differences in the distributional of the data.

\section{Robustness Test}

To test the robustness of the analysis design, we re-estimate the regression discontinuity analysis and difference in difference analysis using the different measurement of tax avoidance. We also re-estimate the difference in difference analysis baseline model by separating each year before and after the introduction of CbCR.

Different Measurement of Tax Avoidance

As pointed out by Gebhart (2017), in accounting and finance empirical studies there are multiple proxies for corporate tax avoidance based on two fundamental measures, viz ETR and book-tax difference (BTD). Even though Hanlon \& Heitzman (2010) set out that BTD by definition only capture non-conforming tax avoidance, they also find out from several discussion of the sources of BTD that BTD measures are closely related to ETR measures that is usually used for tax avoidance measure. Following Hanlon (2005) we estimate total book-tax differences by grossing up current tax expense by statutory tax rate $(25 \%)^{16}$. Accordingly, BTD is calculated as follows: $\mathrm{BTD}=$ Pretax Income $-\frac{\text { Tax Expense }}{0,25}$

\footnotetext{
${ }^{16}$ This $25 \%$ figure is the statutory corporate tax rate in Indonesia as referred to in Article 17 of Income Tax Law
}

However, as explained by Guenther (2014), the use of BTD will cause scale problem where under the same size condition, BTD may be relatively large for a small firm, and relatively small for a large firm. To mitigate such problem when using BTD, following Guenther (2014) we adjust the number using pretax income as scalar. Hence, the scaled BTD (SBTD) is computed as follows:

$$
\text { SBTD }=\frac{\text { Pretax Income }-\frac{\text { Tax Expense }}{0,25}}{\text { Pretax Income }}
$$

A higher (positive) SBTD indicates a higher tax avoidance, and a lower (negative) BTD. suggests a lower tax avoidance.

Figure 3 shows regression discontinuity plot of tax avoidance. As we can examine, the use of BTD as another measurement tax avoidance measurement provides same initial evidence of a decline in tax avoidance by treatment firms in the post-implementation period. Furthermore, nonparametric results in Table 8 also demonstrate a strong consistent result using different measurement of tax avoidance. At the post-implementation period, the coefficients on CBCR 
Table 8

Regression Discontinuity Analysis of Tax Avoidance

\begin{tabular}{lrrr}
\hline \hline Panel A: Pre-implementation period & & & \\
\hline BW & $\mathbf{2 5 0}$ & $\mathbf{4 5 0}$ & $\mathbf{5 5 0}$ \\
\hline CBCR (SBTD) & 0.0773 & 0.0845 & 0.0906 \\
& $(0.762)$ & $(0.787)$ & $(0.805)$ \\
CBCR (SBTD_C) & 0.1224 & 0.1158 & 0.1187 \\
& $(0.556)$ & $(0.499)$ & $(0.513)$ \\
\hline Panel B: Post-implementation period & $\mathbf{2 5 0}$ & $\mathbf{4 5 0}$ & $\mathbf{5 5 0}$ \\
\hline BW & $-0.0936^{*}$ & $-0.1030^{*}$ & $-0.0866^{*}$ \\
CBCR (SBTD) & $(0.032)$ & $(0.015)$ & $(0.048)$ \\
& $-0.1300^{*}$ & $-0.1290^{*}$ & $-0.1340^{*}$ \\
CBCR (SBTD_C) & $(0.031)$ & $(0.031)$ & $(0.024)$ \\
& & &
\end{tabular}

Note: Table 8 reports the results of estimating a nonparametric local linear regression using triangle kernel. Panel A reports the results for the pre-implementation period (2010-2016). CBCR is an indicator variable equal to 1 (0) in 2016-2019. If consolidated revenue in the preceding year is at least (less than) EUR 750M. 250, 450, 550 bandwidths are used to estimate the nonparametric regression in the first, second, and third column. The outcome variable in the first and second row is SBTD. The second row reports the results with the additional covariates (Leverage, Size, and ROA). p-values are reported in the parentheses and * indicates statistical significance at 0.05 .

Table 9

Difference-in-Difference Analysis of Tax Avoidance

\begin{tabular}{lccc}
\hline \hline $\begin{array}{l}\text { Panel A: } \\
\text { Without } \\
\text { reweighting techniques }\end{array}$ & BTD & Panel C: \\
\cline { 2 - 4 } & $\begin{array}{c}\text { Panel A : Without } \\
\text { multivariate reweighting }\end{array}$ & $\begin{array}{c}\text { Panel B: } \\
\text { Entropy Balancing }\end{array}$ & $\begin{array}{c}\text { Panerse Probabilty } \\
\text { Inveighting }\end{array}$ \\
\hline CBCR*POST & $-0.1707^{*}$ & $-0.2872^{*}$ & $-0.1801^{*}$ \\
$\beta_{3}$ & $(0.0416)$ & $(0.012)$ & $(0.028)$ \\
ROA & $-0.0014^{*}$ & $0.0091^{*}$ & -0.0002 \\
& $(0.2908)$ & $(0.006)$ & $(0.471)$ \\
SIZE & 0.0285 & $-0.4322^{*}$ & -0.0473 \\
& $(0.4565)$ & $(0.002)$ & $(0.412)$ \\
LEVERAGE & $0.3227^{*}$ & 0.2221 & $0.3004^{*}$ \\
& $(0.0012)$ & $(0.073)$ & $(0.039)$ \\
INTANG & $-0.8515^{*}$ & -0.1297 & -0.7634 \\
& $(0.0254)$ & $(0.398)$ & $(0,068)$ \\
R\&D & -0.2744 & -1.0445 & -0.1733 \\
& $(0.3644)$ & $(0.087)$ & $(0.399)$ \\
AvgSTR & 2.8132 & $7.2904 *$ & 2.294 \\
& $(0.1667)$ & $(0.022)$ & $(0.230)$ \\
Firm \& Year FE & $\sqrt{ }$ & $\sqrt{ }$ & $\sqrt{ }$ \\
SE Clustered & Firms & Firms & Firms \\
N & 930 & 930 & 930 \\
R-sq. & 0.2911 & 0.7006 & 0.2913 \\
\hline
\end{tabular}

This table reports OLS estimates of the following equation:

$T A_{i t}=\alpha+\beta_{1} C B C R_{i t}+\beta_{2} P O S T_{i t}+\beta_{3} P O S T \times C B C R_{i t}+\beta X_{i t}+\varepsilon_{i t}$

Where TA is the tax avoidance variable and is measured using SBTD. CBCR is an indicator variable equal to (0) 1 in 2010-2019 if the firm is (not) subject to $\mathrm{CbCr}$ rules in 2016-2019. POST is an indicator variable equal to 1 for all years in which the full CBCR requirements were in effect (2016-2019) and 0 otherwise (2010-2015). Xit is a vector of control variables. Panel A estimated using White (1980) heteroscedasticity-consistent diagonal standard errors, Panel B reports OLS estimates of the equation above adjusted for the weights resulted from entropy balancing exercise while Panel $\mathrm{C}$ estimates the equation using inverse probability weighting. All columns are estimated with firm and year fixed effects. Due to the inclusion of the year fixed effect. CBCR and POST terms drops from the estimation and as such these terms are not reported in this table. $p$-values are reported in the parentheses and $*$ indicates statistical significance at 0.05 . 
Table 10

Robustness of Difference-in-Difference Model

\begin{tabular}{|c|c|c|c|c|}
\hline \multirow[t]{2}{*}{ Yearly Analysis } & \multicolumn{4}{|c|}{ ETR } \\
\hline & (1) & (2) & (3) & (4) \\
\hline \multirow[t]{2}{*}{ CBCR_2012 } & 0.0452 & 0.0451 & 0.0423 & 0.0409 \\
\hline & $(0,1532)$ & $(0,1534)$ & $(0,1698)$ & $(0,1778)$ \\
\hline \multirow[t]{2}{*}{ CBCR_2013 } & 0.0149 & 0.0120 & 0.0127 & 0.0111 \\
\hline & $(0,368)$ & $(0,3930)$ & $(0,388)$ & $(0,401)$ \\
\hline \multirow[t]{2}{*}{ CBCR_2014 } & $0.0759 *$ & 0.0712 & 0.0686 & 0.0664 \\
\hline & $(0,0431)$ & $(0,0541)$ & $(0,0613)$ & $(0,0678)$ \\
\hline \multirow{2}{*}{ CBCR_2015 } & $0.1455^{*}$ & $0.1417 *$ & $0.1412 *$ & $0.1388^{*}$ \\
\hline & $(0,0005)$ & $(0,0007)$ & $(0,0008)$ & $(0,0001)$ \\
\hline \multirow[t]{2}{*}{ CBCR_2016 } & $0.0903 *$ & $0.0843^{*}$ & $0.0844 *$ & $0.0816^{*}$ \\
\hline & $(0,021)$ & $(0,029)$ & $(0,0289)$ & $(0,034)$ \\
\hline \multirow[t]{2}{*}{ CBCR_2017 } & $0.1160 *$ & $0.1099 *$ & $0.1103^{*}$ & $0.1073 *$ \\
\hline & $(0,004)$ & $(0,007)$ & $(0,0067)$ & $(0,008)$ \\
\hline \multirow[t]{2}{*}{ CBCR_2018 } & 0.0908* & $0.0850 *$ & 0.0855* & $0.0826^{*}$ \\
\hline & $(0,0200)$ & $(0,0278)$ & $(0,0275)$ & $(0,0325)$ \\
\hline \multirow[t]{2}{*}{ CBCR_2019 } & 0.0829* & 0.0786* & $0.0785^{*}$ & $0.0755 *$ \\
\hline & $(0,0304)$ & $(0,0380)$ & $(0,039)$ & $(0,0455)$ \\
\hline Firm \& Year FE & $\sqrt{ }$ & $\sqrt{ }$ & $\sqrt{ }$ & $\sqrt{ }$ \\
\hline $\mathrm{N}$ & 930 & 930 & 930 & 930 \\
\hline $\mathrm{R}$-sq. & 0.2970 & 0.2990 & 0.3005 & 0.3008 \\
\hline
\end{tabular}

TA is the tax avoidance variable and is measured through ETR. CBCR is indicator variable equal to (0) 1 in 2012-2019 if the firm is (not) subject to CbCR rules in 2016-2019. 2012-2019 are indicator variables equal to 1 for year 2012-2019 (respectively) and 0 otherwise. $\mathrm{X}_{\mathrm{it}}$ is a vector of control variables and the coefficients on these terms are omitted for brevity. All columns are estimated with firm and year fixed effects. Due to the inclusion of the fixed effect. the following estimation and as such are not reported: CBCR and 2012-2019. Table 7 estimated using original standard errors. $p$-values are reported in the parentheses and * indicates statistical significance at 0.05 .

are negative and statistically significant in all bandwidths. It shows that there is a decline in tax avoidance by treatment firms in the post-implementation period. Both results (graphical presentation and nonparametric) bring to a conclusion that either using ETR or BTD as measurement of tax avoidance gives similar findings.

Same results are also shown in difference in difference analysis. Table 9 exhibits a persistent result that either using multivariate reweighting techniques or not, treatment firms have lower BTD and hence, lower tax avoidance following the introduction of $\mathrm{CbCR}$ relative to control firms.

\section{Robustness of Difference-In-Differences Model}

To obtain robust estimates in difference-in-differences model, the dependent variable in the treatment and control groups should follow the same trend (Joshi 2020). Accordingly, to mitigate concerns that control firms have significantly different ETRs in the pre-implementation period and to understand the timing of the changes in tax avoidance, as constructed by Joshi (2020), we estimate the baseline model as abovementioned by including separate year indicators and interaction variables for four years before and four years after the introduction of CbCR.

The robustness model is as follows:

$T A_{i t}=\alpha+\beta_{1} C B C R_{i t}+\beta_{2} 2012+\beta_{3}$ $2013+\beta_{4} 2014+\beta_{5} 2015+\beta_{6} 2016+\beta_{7}$ $2017+\beta_{8} 2018+\beta_{9} 2019+\beta_{10} C B C R_{i t} *$ $2012+\beta_{11} C B C R_{i t} * 2013+\beta_{12} C B C R_{i t} *$ $2014+\beta_{13} C B C R_{i t} * 2015++\beta_{14} C B C R_{i t}$ $* 2016+\beta_{15} C B C R_{i t} * 2017+\beta_{16} C B C R_{i t}$ $* 2018+\beta_{17} C B C R_{i t} * 2019+\beta X_{i t}+\mathrm{FE}_{\mathrm{it}}$ $+\varepsilon_{i t}$

The results of this estimation as reflected in Table 10 suggest that there was no significant difference in tax avoidance in the two groups of firms before 2015. However, commencing in 2015, there is an increase in the ETRs of the treatment firms relative to the control firms and this effect increases 
over time. Furthermore, a positive and significant coefficient on the interaction between 2015 and CBCR indicates that there were some spillover effects of CbCR with Indonesia MNEs responding before the official adoption of these regulations, in 2016 and 2017 respectively. This could be understood considering the public consultation of BEPS Action 13 project has been performed since early 2014.

The findings in this section suggest that the primary results documented in Table 7 (i.e. the introduction of CbCR led to a significant decline in tax avoidance) are not driven by an increase in tax avoidance in the control firms and can be attributed to the change in tax behavior of the treatment firms.

\section{CONCLUSION}

By enacting MoFR-213/2016 and DGT-29/2017, Indonesia has implemented BEPS Action 13 on Country-by-Country Reporting (CbCR). This private disclosure is expected to provide tax authority with greater information on the activity of MNEs wherever they operate, including their tax payment and several financial indicators presented on aggregated and jurisdictional basis. Obtaining incremental insights, tax authority is expected to increase tax enforcement, thus decrease corporate tax avoidance by increasing the cost of avoidance.

Despite ample research examining how corporate behavior alters following the introduction of $\mathrm{CbCR}$ requirement as public disclosure, there is still limited research on the impact of $\mathrm{CbCR}$ as private disclosure. The only study focusing on the impact of CbCR as a private disclosure on MNEs tax behavior is Joshi (2020) which solely focuses on EU headquartered MNEs.

Nevertheless, up until now, there has not been any study examining the impact of $\mathrm{CbCR}$ requirement as a private tax disclosure on corporate tax behavior in Indonesia. Considering the nature of Indonesia as a capital importing country, this study will complement the research of Joshi (2020) by using all MNEs operating in Indonesia, irrespective where the UPEs reside. Accordingly, this research aims to understand the impact of $\mathrm{CbCR}$ as a private disclosure in Indonesia.

By using regression discontinuity design and difference-in-differences analysis, as well as separating control group and treatment group based on the threshold in BEPS Action 13 (i.e. EUR 750 million cutoff), at the firm level we find a solid evidence of an increase in the effective tax rates (ETRs) of MNEs operating in Indonesia whose UPEs are subject to CbCR in the four year of post-adoption period (i.e. 20162019).

This study offers some contributions. First, we enhance the existing literature by providing empirical evidence on how a private disclosure requirement could alter the corporate tax behavior. In this study, we document a decrease of corporate tax avoidance of the MNEs operating in Indonesia following the implementation of CbCR as a private disclosure. Second, this study provides practical implication for the DGT since it helps in evaluating whether the adoption of CbCR as mandated by BEPS Action 13 has achieved the desired results, i.e. providing transparency and thus lowering the potential of tax avoidance. Considering the result of this study, DGT should continue the adoption of $\mathrm{CbCR}$ requirement for MNEs in Indonesia so that the information gleaned from CbCR could be used for tax law enforcement.

However, our study definitely has some limitations. First, despite having employed difference-in-differences analysis and the following robustness test, the estimates generated from the analysis might still be local average treatment effects (Leuz and Wysocki 2016). Second, this study has not described through which channel the CbCR could finally deter tax avoidance, whether through the increase of enforcement by DGT or through the reputational costs of potential information leakage that MNEs face. Furthermore, this study primarily uses ETR as a proxy to measure 
corporate tax avoidance and BTD upon robustness check. It accordingly opens for further study to use different proxies of tax avoidance.

Given some limitations above, we suggest for the use of another estimation method addressing the issue of local average treatment effects. Likewise, to test through which channel the CbCR could finally deter tax avoidance, we also suggest the future research to take into account both tax authority enforcement variable and reputational costs variable into the equation as moderating variables.

Disclaimer: The views expressed herein are those of authors and do not necessarily represent or reflect the views of the institution where the authors worked for or associated with.

\section{REFERENCES}

Abadie, A., and G.W. Imbens. 2011. BiasCorrected Matching Estimators for Average Treatment Effects. Journal of Business \& Economic Statistics, 29 (1), 1-11.

Allingham, M.G., and A. Sandmo. 1972. Income Tax Evasion: A Theoretical Analysis. Journal of Public Economics, 1(3-4), 323-338.

Babbie, E. 2007. The Practice of Social Research $11^{\text {th }}$ Edition. Belmont, CA: Thomson Wadsworth.

Bozanic. Z., J. L. Hoopes, J. R. Thornock, and B. M. Williams. 2017. IRS Attention. Journal of Accounting Research, 55(1), 79-114.

Brown, R. J., B. N. Jorgensen, and P. F. Pope. 2019. The Interplay Between Mandatory Country -By -Country Reporting. Geographic Segment Reporting. and Tax Havens: Evidence from the European Union. Journal of Accounting and Public Policy, 38(2), 106-129.

Chen, K. P., and C. C. Chu. 2005. Internal Control Versus External Manipulation: A Model of Corporate
Income Tax Evasion. RAND Journal of Economics, 151-164.

Chen, S. 2017. Do Investors Value Corporate Tax Return Information? Evidence from Australia. Ph.D. Dissertation. The University of Texas at Austin.

Chen, S., Y. Huang, N. Li, and T. Shevlin. 2019. How Does Quasi-Indexer Ownership Affect Corporate Tax Planning?. Journal of Accounting and Economics, 67(2-3), 278-296.

Chetty, R., J. N. Friedman, and J. E. Rockoff. 2014. Measuring the Impacts of Teachers II: Teacher Value-Added and Student Outcomes in Adulthood. American Economic Review, 104(9), 2633-79.

Cobham, A., and P. Janský. 2018. Global Distribution of Revenue Loss From Corporate Tax Avoidance: ReEstimation and Country Results. Journal of International Development, 30 (2), 206-232.

Crocker, K. J., and J. Slemrod. 2005. Corporate Tax Evasion With Agency Costs. Journal of Public Economics, 89 (9-10), 1593-1610.

De Simone, L., and M. Olbert. 2019. Real Effects of Private Country-byCountry Disclosure. Available at SSRN 3398116.

Desai, M. A., A. Dyck, and L. Zingales. 2007. Theft and Taxes. Journal of Financial Economics, 84 (3), 591623.

Directorate General of Taxes. 2017. Director General of Taxes Regulation No. 29/PJ/2017 concerning Procedures for Managing Countryby-Country Reporting. Downloaded on 25 July 2020, http://www.pajak.go.id/cbcr.

Donohoe, M. P. 2015. The Economic Effects of Financial Derivatives on Corporate Tax Avoidance. Journal of Accounting and Economics, 59(1), 124.

Dutt, V.K., et al. 2019. Increasing Tax Transparency: Investor Reactions to 
the Country-by-Country Reporting Requirement for EU Financial Institutions. International Tax and Public Finance, 26(6), 1259-1290.

Dyreng, S. D., M. Hanlon, and E. L. Maydew. 2008. Long-run Corporate Tax Avoidance. The Accounting Review, 83(1), 61-82.

Edwards, A., C. Schwab, and T. Shevlin. 2016. Financial Constraints and Cash Tax Savings. The Accounting Review, 91(3), 859-881.

Fernandez, M., M. M. Almaazmi, and R. Joseph. 2020. Foreign Direct Investment in Indonesia: An Analysis from Investors Perspec-tive. International Journal of Economics and Financial Issues, 10 (5), 102-112.

Gao, Y., M. Khan, and L. Tan. 2017. Further Evidence on Consequences of Debt Covenant Viola-tions. Contemporary Accounting Research, 34 (3), 1489-1521.

Gebhart, M. S. 2017. Measuring Corporate Tax Avoidance-An Analysis of Different Measures. Junior Management Science, 2 (2), 43-60.

Guenther, D. A. 2014. Measuring Corporate Tax Avoidance: Effective Tax Rates And Book-Tax Differences. Available at SSRN 2478952.

Gupta, S., and K. Newberry. 1997. Determinants of The Variability in Corporate Effective Tax Rates: Evidence From Longitudinal Data. Journal of Accounting And Public Policy, 16 (1), 1-34.

Hahn, J., P. Todd, and W. Van der Klaauw. 2001. Identification and Estimation of Treatment Effects with A RegressionDiscontinuity Design. Econometrica, 69 (1), 201-209.

Hanlon, M. 2005. The Persistence and Pricing of Earnings, Accruals, and Cash Flows When Firms Have Large Book-Tax Differences. The Accounting Review, 80 (1), 137-166.

Hanlon, M., and S. Heitzman. 2010. A Review of Tax Research. Journal of
Accounting and Economics, 50 (2-3), 127-178.

Hanlon, M. 2018. Country-by-Country Reporting and the International Allocation of Taxing Rights. Bulletin for International Taxation (Volume 72), No. 4/5. Journals IBFD.

Hoopes, J. L., D. Mescall, and J.A. Pittman. 2012. Do IRS Audits Deter Corporate Tax Avoidance?. The Accounting Review, 87(5), 1603-1639.

Hainmueller, J., and Y. Xu. 2013. Ebalance: A Stata Package for Entropy Balancing. Journal of Statistical Software, 54 (7).

IASB. 2015. IFRS 10 Consolidated Financial Statements. Accessed on 7 January 2021.

https://www.iasplus.com/en/standard s/ifrs/ifrs 10.

Jensen, M. C., and W. H. Meckling. 1976. Theory of The Firm: Managerial Behavior, Agency Costs and Ownership Structure. Journal of Financial Economics, 3 (4), 305-360.

Joshi, P., E. Outslay, and A. Persson. 2019. Does Public Country-by-Country Reporting Deter Tax Avoidance and Income Shifting? Evidence from the European Banking Industry. Contemporary Accounting Research.

Joshi, P. 2020. Does Private Country-byCountry Reporting Deter Tax Avoidance and Income Shifting? Evidence from BEPS Action Item 13. Journal of Accounting Research, 58 (2), 333-381.

Khan, M., S. Srinivasan, and L. Tan. 2017. Institutional Ownership and Corporate Tax Avoidance: New Evidence. The Accounting Review, 92 (2), 101-122.

Klassen, K. J., and S. K. Laplante. 2012. The Effect of Foreign Reinvestment and Financial Reporting Incentives on Cross-Jurisdictional Income Shifting. Contemporary Accounting Research, 29 (3), 928-955.

Lee, D. S., and T. Lemieux. 2010. Regression Discontinuity Designs in 
Economics. Journal of Economic Literature, 48 (2), 281-355.

Leuz, C., and P. D. Wysocki. 2016. The Economics of Disclosure and Financial Reporting Regulation: Evidence and Suggestions for Future Research. Journal of Accounting Research, 54 (2), 525-622.

Mills, L. F. 1998. Book-Tax Differences and Internal Revenue Service Adjustments. Journal of Accounting Research, 36 (2), 343-356.

Ministry of Finance of Republic of Indonesia. 2016. Minister of Finance Regulation No. 213/PMK.03/2016 concerning Additional Documents and/or Information Compulsorily Retained by Taxpayers Conducting Related Party Transactions and Its Administration Procedures.

Downloaded on 25 July 2020, http://www.pajak.go.id/cbcr.

Murphy, R. 2003. A Proposed International Accounting Standard: Reporting Turnover and Tax by Location. Association for Accountancy and Business Affairs. Available at: $<$ http://visar.csustan.edu/aaba/Propos edAccstd.pdf $>$.

Nadaraya, E. A. 1964. On Estimating Regression. Theory of Probability \& Its Applications, 9 (1), 141-142.

OECD. 2015. Transfer Pricing Documentation and Country-byCountry Reporting. Action 13 - 2015 Final Report. OECD/G20 Base Erosion and Profit Shifting Project. OECD Publishing. Paris.

https://doi.org/10.1787/97892642414 80-en.

OECD. 2017. Country-by-Country Reporting: Handbook on Effective Tax Risk Assessment. OECD. Paris. Downloaded on 10 July 2020, www.oecd.org/tax/beps/country-bycountry-reporting-handbook-oneffective-tax-risk-assessment.pdf

OECD. 2020. Country-by-Country Reporting Exchange Relationships. Downloaded on 30 July 2020, https://www.oecd.org/tax/beps/count ry-by-country-exchangerelationships.htm

Overesch, M., and H. Wolff. 2019. Financial Transparency to the Rescue: Effects of Country-byCountry Reporting in the EU Banking Sector on Tax Avoidance. Available at SSRN 3075784.

Pawar, B., and M. Sabharwal. 2016. Country-by-Country Reporting: Blind Men and An Elephant. Accessed on 28 July 2020 ,

https://www.financialexpress.com/op inion/country-by-country-reportingblind-men-and-an-elephant/221706/.

Richardson, G., and R. Lanis. 2007. Determinants of The Variability in Corporate Effective Tax Rates and Tax Reform: Evidence from Australia. Journal of Accounting and Public Policy, 26 (6), 689-704.

Richardson, G., G. Taylor, dan R. Lanis. 2013. The Impact of Board of Director Oversight Characteristics on Corporate Tax Aggressiveness: An Empirical Analysis. Journal of Accounting and Public Policy 32, 6888.

Roberts, M. R., and T. M. Whited. 2013. Endogeneity in Empirical Corporate Finance 1. In Handbook of the Economics of Finance, 2, 493-572.

Sansing, R. C. 1993. Information Acquisition in A Tax Compliance Game. Accounting Review, 874-884.

Scholes, M., and M. Wolfson.1992. Taxes and Business Strategy: a Planning Approach. Prentice-Hall, Inc., Engelwood Cliffs, NJ.

Shackelford, D. A., and T. Shevlin. 2001. Empirical Tax Research in Accounting. Journal of Accounting and Economics, 31(1-3), 321-387.

Siegfried, J. 1972. The Relationship Between Economic Structure and The Effect of Political Influence: Empirical Evidence From The Federal Corporation Income Tax 
Program. $\quad \mathrm{PhD}$ dissertation, University of Wisconsin.

Slemrod, J. 2004. The Economics of Corporate Tax Selfishness. National Tax Journal 57, 877-899.

Spengel, C. 2018. Country-by-Country Reporting and the International Allocation of Taxing Rights: Comments to Michelle Hanlon. Bulletin for International Taxation 72 (4-5).

Starr, E., and B. Goldfarb 2020. Binned Scatterplots: A Simple Tool to Make Research Easier and Better. Strategic Management Journal.

Stuart, E. A., et al. 2014. Using Propensity Scores in Difference-in-Differences Models to Estimate the Effects of a Policy Change. Health Services and Outcomes Research Methodology, 14 (4), 166-182.

Tan, L. 2013. Creditor Control Rights, State of Nature Verification, and Financial Reporting Conservatism. Journal of Accounting and Economics, 55 (1), 122.

Towery, E. M. 2017. Unintended Consequences of Linking Tax Return Disclosures to Financial Reporting for Income Taxes: Evidence from Schedule UTP. The Accounting Review, 92 (5), 201-226.

Tran, A. V. 1997. Causes of The Book-Tax Income Gap. Austl. Tax F., 14, 253.

Trochim, W. M. K., and J. P. Donnelly. 2006. The Research Methods Knowledge Base, $3^{\text {rd }}$ Edition. Cincinnati, OH: Atomic Dog.

Watson, G. S. 1964. Smooth Regression Analysis. Sankhyā: The Indian Journal of Statistics, Series A, 359372.

White, H. 1980. A HeteroskedasticityConsistent Covariance Matrix Estimator and A Direct Test for Heteroskedasticity. Econometrica: Journal of the Econometric Society, 817-838.

Wilde, J. H., and R.J. Wilson. 2018. Perspectives on Corporate Tax
Planning: Observations from the Past Decade. The Journal of the American Taxation Association, 40 (2), 63-81. 